\title{
Hepatoblastoma with Combined Fetal and Embryonal Epithelial Differentiation
}

National Cancer Institute

\section{Source}

National Cancer Institute. Hepatoblastoma with Combined Fetal and Embryonal Epithelial

Differentiation. NCI Thesaurus. Code C7094.

A hepatoblastoma composed of cells resembling fetal epithelial cells and small round cells resembling blastema cells. 